\title{
Innovation development in Russia: the value aspect
}

\author{
Alexander Y. Chmykhalo ${ }^{1,}$, , Olga V. Mikhailova ${ }^{1}$, Nikolay A. Vtorushin ${ }^{1}$, Roman A. Bykov ${ }^{2}$ \\ ${ }^{1}$ Tomsk polytechnic university, 634050 Lenina str., 30, Tomsk, Russia \\ ${ }^{2}$ Tomsk state university, 634050 Lenina str., 36, Tomsk, Russia
}

\begin{abstract}
The article examines the problems of the transition of modern Russia towards the formation of an innovative economy, with a special emphasis on the investigation of the key challenges that Russian universities face while training engineers equipped for innovative activities. The paper considers the impact of cultural characteristics of the Russian society on the organization and content of an education process in a technical university, on "producing" engineers capable of developing innovation. In our analysis we use a comparative approach, as well as the outcomes of the etnometric studies based on the method by G. Hofstede. The study presents the comparative analysis of the organization and content of engineering training at two universities representing Russia and the United States. The results of the study show that further productive development of the Russian system of engineering education towards integration with Western systems is possible provided that the value orientation of the Russian state and society is significantly revised.
\end{abstract}

\section{Introduction}

The article considers the challenges of the transition of modern Russia towards the formation of an innovative economy. This research focuses on the analysis of the impact of the value imperatives of the Russian society on the organization and content of engineering education in Russia, on the innovation orientation of the academic activities. Besides, the study aims to identify the major contradictions and constraints in the content and implementation of the education process that Russian universities face while encouraging students to pursue innovation.

At present, the Russian economy is going through quite a difficult period, caused by, primarily, the technological backwardness of Russia, and the restricted access to new technologies due to the sanctions imposed by Western countries. Besides, the current negative situation has resulted largely from the country's commitment to the resource-based economy. There exist some other problems in the development of the country's economy, with human resourcing being the most pressing one.

Higher education in the USSR was quite successful in tackling the task of training engineers for the national economy, thus ensuring it the position of one of the world's most industrially advanced countries. By the middle of the 1980-s the USSR had held leading positions in the world according to some economy's performance indicators. With that, the dependence of the organization of the soviet system of engineering training

\footnotetext{
${ }^{a}$ Corresponding author: sanichtom@inbox.ru
}

on the socio-cultural conditions was obvious. It was determined by the directives, put forward by the government, and the value imperatives that all engineers were to be guided by in their professional activities. In general terms those value imperatives were for engineers to lay the foundations for the development of the communist society by boosting state-of-the-art technology, science, and industry.

The situation in modern Russia has changed significantly. Along with the public sector of the economy in Russia there has appeared the private sector as well. During the period from the end of the 20-th to the beginning of the 21-st century the country was deindustrialized. The obvious commitment of the Russian economy to the development of the resource-based model has increasingly moved it away from the world's technologically advanced countries that can boost significant innovative breakthroughs. The transformation of the socio-cultural norms in the society was to have an adequate impact on engineering training, on the whole system of education, on the values people miss in their professional activities. It is obvious that the system of engineering training left behind by the Soviet Union has failed to accommodate the new economic environment and the imperatives of the time. The transformation of the socio-cultural background in Russia caused changes of the professional component of an engineering training program, which, however, have not been implemented in full yet. Therefore, this problematic situation has to be scrutinized and adequate solutions need to be offered. 
Furthermore, the Strategy of Innovative Development adopted in 2011 lays down a new objective for Russia's economic development, which is to build an innovative economy. That inevitably entails new priorities in the reorganized system of engineering training, which enable the production of a new generation of cognizant, creatively-thinking, innovationoriented young professionals, who have acquired not only knowledge, abilities and skills necessary to work at modern enterprises, but also aspiration and drive to create novelty products, technologies, companies, industries, and, as a consequence, a new innovative economy with prevailing IT and high-tech businesses.

Since the modification of the socio-cultural characteristics of the Russian society over the past 25 years has determined the changes in both the country's image and its economic and education systems, it is of urgent importance to understand the role of these characteristics in the transformation of the system of engineering training.

In this study, we try to give answers to the following questions: What is the impact of cultural characteristics of the Russian society on the organization and content of the education process in a technical university, on the organization of innovative activities? What influence do the cultural characteristics of the countries dominating in innovative development have on the content and organization of the engineering training system, on the encouragement of students' involvement in innovation activities? Is it possible to transfer foreign education institutions' practices to Russian high schools in order to align the national system of training engineers with the emerging challenges of an innovation-driven economy?

The study focuses on the two universities, representing Russia and the United States (the leading country in the field of innovation development):

1) Tomsk Polytechnic University (TPU, Russia), which positions itself as one of the leaders of engineering education in Russia,

2) Arizona State University (ASU, USA), which is known for its focus on the innovative development as much as the world's acknowledged leaders, such as MIT or University of Texas at Austin.

Our choice is due to the fact that The Programme of the TPU Competiveness Enhancement puts ASU into the reference group of universities as one of the models for a Russian university to follow. The policy document of the TPU points out the following advantages of ASU: its outstanding academic achievements in different geographical, cultural and linguistic backgrounds; focus on technology; consistent ranking among the top universities according to different international ratings polls. Another determining factor in our choice, even more central for the present study, is the fact that this university is one of the most successful universities in the USA in terms of establishing start-up companies that put into practice the results of research activities. Only in 2012 the University attracted more than \$ 200 million in financing and aided to create more than 55 companies.

In addition, we have noticed that while bearing certain resemblance the universities differ greatly in the outcomes of innovative activities, which also justifies our reference to these universities in the comparative analysis.

The results of this research will help to understand the peculiarities of the higher education system operation within the national innovation systems, to elicit the role of cultural traits in the development of peoples and states. The conclusions drawn can be integrated into the national strategy for the designing and functioning of Russia's higher education and innovation systems.

The structure of the paper is as follows:

Section 1. Introduction and justification of the study;

Section 2. The theoretical background;

Section 3. Methodology of the research;

Section 4. The analysis of the cultural characteristics of the Russian and American societies and their impact on the organization of educational activities in technical universities of Russia and the United States (exemplified by TPU and ASU);

Section 5. Conclusions and policy implications.

\section{The theoretical background}

It has become evident that the development of an innovation-driven economy of any country depends for its success on human resourcing. The issue of providing modern economy with engineers has been covered in terms of different perspectives. Many scientific papers tend to represent the problem of supporting innovative development as a complex one, requiring a system approach for its analysis, according to which creativity, innovation and entrepreneurship (CIE) make up an inseparable entity. It is proposed to consider this system not only as a driving force for a country's social and economic development, but also as a meta-competence to be emphasized greatly in the education system, particularly in the system of engineering education [1].

Many developed countries that have been forced to make technological and social changes in their education process still debate about issues concerning the necessity to integrate into the current universities' curricula aspects related to educating enterprising, creativeminded, innovation-oriented graduates. Of greater importance is this issue for engineering education that strives both to carry out advanced scientific and technological research and to deliver new products and technologies in order to meet the society's needs and priorities [2, 3, 4]. Universities are becoming increasingly aware of the need to educate engineers who are capable of designing new products and services, are creative in their activities, possess skills and competences to identify and meet both social needs and market demands $[5,6]$.

Though the number of experiments and research papers on entrepreneurship and innovation education in western countries has increased [4, 7, 8, 9], they have failed to provide a comprehensive list of competences a student should acquire to be prepared for entrepreneurial and innovation-oriented activity. The papers describe mainly some specific practices of entrepreneurship training $[10,11,12]$, with a special emphasis on particular skills and features of entrepreneurial, creative 
or innovative activities, rather than representing those competences as a comprehensive integral structure [13, $14,15]$.

It can be stated that despite the abundance of various discourses for creativity, innovation and entrepreneurship, there is no perception of those as a single conceptual integrity. The place of those competencies in the general system of an engineering graduate's outcomes is still not clear. The vagueness of ideas about which competencies a university student should develop has led to a debate in a society about the influence of economic and social environment on the process of new knowledge formation and innovation development at university [16]. In addition, in recent years much research has been done into the effects of a country's cultural background on its innovation potential, the specific character of its innovation system, as well as its higher education system [17].

Russian scholars are not unanimous about the approaches to be used to redesign the system of engineering education. On the one hand, some of them view the present education system as the continuity of the "national system of engineering training", which, due to the reforms it has undergone, has been drifting farther away from its origins, thus undermining its quality. Therefore, commitment to the best traditions of the national engineering training is thought to be a dominant factor in the evolution of engineering training in Russia. According to I.Fedorov, V.Medvedev, A.Aleksandrov et al., in particular, engineering fundamentals have always been the backbone of the national system of engineering education, enabling to maintain a high level of training qualified engineers in Russia [18]. Thus, engineering fundamentals should be prioritized in an academic environment as a crucial factor of its development.

On the other hand, the above-mentioned authors argue that for all the accomplishments of the national engineering high school, present-day challenges cause radical changes in the very system of engineering education, forcing it to be more universal, more interdisciplinary. A few decades ago, for example, an engineer was supposed to be well educated in his major; in contrast, nowadays they have to be multidisciplinary [19].

Furthermore, some authors point out the inability of the Russian industry to offer the best industrial practices for the system of engineering education, which will inevitably have negative implications for its quality. As a consequence, other authors suggest resorting to the experience accumulated by countries demonstrating the consistent correlation of the above-mentioned aspects with the best industrial practices. Agranovic V.L., Pokholkov Y.P., Chuchalin A.I., Podlesny S.A., in particular, recommend applying the concept of CDIO, developed at MIT $[20,21]$. Thus, the main idea of the second approach is to explore the best engineering practices in the world and justify their transfer to Russia.

The third approach, rather than contraposing Russian and foreign practices of engineering training, seeks the ways of integrating those, as complementing each other, into the system of higher education. For this integration to take place certain conditions need to be created, the conditions that are not apparent yet, which, as a consequence, arouse a lot of debate [22].

We believe that the results of this study will make it possible to give a more sound assessment of the feasibility of each of the presented approaches to the reorganization of the Russian system of engineering training, by providing arguments both in favor of and against each of them.

\section{Methodology of the research}

The specific character of the problem, which is related to the explication of cultural issues in the reorganization of the system of engineering training for the purpose of meeting the challenges of an innovative economy, determined the use of a comparative method as a primary one in order to address a range of research tasks.

We base this study on the hypothesis that it is the indicators characterizing cultural values of any country that ultimately govern the specific organization and content of higher education in general and technical education in particular. In their turn, these cultural values, inherent in societies of different countries, determine the different outcomes of innovation activities. That led us to use in our investigation the results of the studies of behavior motivations conducted by using the methodology of the social psychologist $\mathrm{G}$. Hofstede. In this paper we use the comparative results of the study of the socio-cultural characteristics of the two countries - the United States and Russia, presented by the Hofstede centre in February, 2015. These dimensions of the national culture represent general assessment and have not been differentiated depending on the characteristics of the respondents, although it is possible. As the results of the etnometric studies of students' mentality are not available for us, we refer to the data describing the general cultural background in the country. It was of greater importance for us to explore how the dominant national cultural values influence the organization and the content of university education in these countries, and, ultimately, determine the mode and the outcomes of innovative practices.

\section{The analysis of the cultural characteristics of the Russian and American societies and their impact on the organization of educational activities in technical universities of Russia and the United States (exemplified by TPU and ASU)}

In his study of national cultures G. Hofstede differentiates the following "cultural dimensions": Power Distance (high versus low) - is the degree of inequality of power distribution accepted by the members of the society; Individualism versus Collectivism. In collectivist societies members of different tightly-knit in-groups (families, organizations, etc) are expected to take care of each other in exchange for "unquestioning loyalty", while individualists are 
centered on themselves and their immediate family; Masculinity (high versus low). The Masculine type society is characterized by the values that instigate achievement and success. The Feminine society is more oriented at the quality of life and caring for others; Uncertainty Avoidance (high versus low) shows the degree of people's anxiety over some uncertain and ambiguous situations they may find themselves in and the desire to avoid them; Long Term Orientation (long term versus short term orientation) - prioritized orientation of people pragmatic pursuits, or future orientation; Indulgence (Indulgence versus Restraint) - is the degree to which people are trying to control their desires and impulses. A Relatively weak control is referred to as "indulgence" and a relatively strong control is called "restraint". The results of the study of these dimensions in Russia and the United States are represented in the summary table below (Table 1.)

Table 1. Cultural dimensions in Russia and the USA (G.Hofstede)

\begin{tabular}{|l|l|l|l|l|l|l|}
\hline & $\begin{array}{l}\text { Power } \\
\text { distan- } \\
\text { ce }\end{array}$ & $\begin{array}{l}\text { Individ } \\
\text { ualism }\end{array}$ & $\begin{array}{l}\text { Masculi } \\
\text { nity }\end{array}$ & $\begin{array}{l}\text { Uncerta } \\
\text { inty } \\
\text { avoidan } \\
\text { ce }\end{array}$ & $\begin{array}{l}\text { Long } \\
\text { Term } \\
\text { Orientat } \\
\text { ion }\end{array}$ & $\begin{array}{l}\text { Indulge } \\
\text { nce }\end{array}$ \\
\hline $\begin{array}{l}\text { United } \\
\text { States }\end{array}$ & 40 & 91 & 62 & 46 & 26 & 68 \\
\hline Russia & 93 & 39 & 36 & 95 & 81 & 20 \\
\hline
\end{tabular}

Within the framework of the present research we are not able to analyze the influence of all the above mentioned dimensions on the organization and the content of a training process in the field of engineering. However, even the study of a few of them will make it possible to draw some sound conclusions about their effect on engineering education and, as a consequence, on the specific features and outcomes of innovative processes in these countries. The present study covers only the first two characteristics, that is, Power Distance and Individualism and their role in the organization and the content of education in the two universities.

While analyzing the impact of the cultural dimension of the Power Distance on the universities' policies and activities, we take into account the following scores interpretation:

- low power distance indicates the adherence to the horizontal social contract, the maintenance of coordinated conduct through civil institutions by using transparent and reproducible algorithms, the availability of competitiveness;

- high power distance indicates the adherence to the vertical social contract characterized by the asymmetry, with the government always taking the initiative. The exchange of signals between the actors goes one-way from the authorities to the society. The typical features of this type society are hierarchical relations and lack of arranged coordinated conduct and response to that.

Tomsk Polytechnic University exhibits a large degree of Power Distance, in contrast to Arizona State University, which is due to the following characteristics of the universities:
1) at the beginning of the XXI century both universities faced the urgency of redesigning and creating their programs of development. While in Russia those reforms were initiated by the government, in the American university (AZU) the initiative group included the faculty members and representatives of the society.

The national program "Project 5-100" is aimed at enhancing the competitiveness of a group of leading Russian universities in the global market of educational and research programs. The TPU Development Project, being part of that program, is supposed to pursue the prescribed course.

The Development Project of Arizona State University called the «New American University» was created by Michael M. Crow, president of Arizona State University and his coauthor William B. Dabars, a historian. The «New American University» model was conceived by M. Crow, when he moved from Columbia University to Arizona State in 2002. This model was engendered by the growing tendency in top American universities towards more selective admission procedure practices, which threatened to undermine America's future, the collective quality of life, standard of living, and national economic competitiveness. The project has become the foundational prototype for new American research universities.

2) The two universities differ also in the missions and goals laid down in their policy documents. While TPU's activities are state-interest-oriented, AZU is targeted at the local community and its members. The mission of TPU is to enhance the country's competitiveness, whereas the mission of AZU is to demonstrate academic excellence and to maintain the fundamental principle of university accessibility to all students representing the socioeconomically and ethnically diverse population of Arizona, for them to be able to gain research skills.

3) Even though both TPU and AZU have vertical management systems, they differ greatly. The preponderant participation of the national government in the Russian university's management is obvious, the participation that is not balanced by the level of involvement of the local community. This ramified and multiple vertical management structure leads to duplicating their powers and responsibilities, to the lack of contact with local civil society. This conclusion can be illustrated by the following comparative examples:

- the administrative bodies of TPU are numerous: the Supervisory Board; the TPU Assembly (is held at least once every 5 years), the Academic Council (senate), the Rector, the University President (currently not available), the Board of Trustees, Academic Councils of the departments, the Students' Council.

The administrative system of AZU consists of the two major structures: 1) The Arizona Board of Regents (ABOR), the governing body for all public universities of Arizona and 2) the President of the University, who is considered the Chief Executive Officer and the Chief Budget officer of the institution;

- the main administrative body of TPU is represented mainly by the governmental officials, while members of the local civil society dominate in the management of AZU. According to the Charter of TPU, one of its 
highest governing bodies is the Supervisory Board, which currently includes 11 members, namely: 3 representatives of state universities ( 2 people from the administration of TPU and 1 person from the Higher School of Economics), one representative of the Tomsk Regional Administration (the Governor), 3 members are the officials at the federal and regional levels, 2 representatives of the public corporations and only 2 members of the Council represent communities, which can be referred to as the ones relatively independent from the state, that is the Russian Academy of Sciences and a private company.

ABOR is the governing body for Universities in the state of Arizona that provides strategic guidance on academic and students issues; finances and human resources; training programs; financial assistance programs; universities' development plans; strategic plans; legal issues, and others. The Board of Regents consists of 12 members, with 11 of them being entitled to vote and one non-voting member. Eight volunteer Regent members, who represent the state's establishment - lawyers, businessmen, public figures, are appointed by the Governor of Arizona for an 8-year term. The Board of Regents also includes two students serving a two-year term, who are non-voting apprentices during the first year. The Governor and the Superintendent of Public Instruction act as ex officio members.

In an effort to achieve the goals and objectives of management the TPU Rector has limited contact with local civil society representatives, while the president of ASU cooperates closely with those. There are no representatives of the local civil community within the TPU Rector's official circle of contacts (the Board of Supervisors, the Academic Council (senate), the Board of Trustees, the Board of Patriarchs, and the International Scientific Council). The Office of the President of AZU has several advisory boards: the Academic Council, Community Council, Economic Council, Vision Council, National Visiting Committee, staffed not only by academics, but also representatives of the public organizations of the state.

Further we examine the influence of Individualism (versus Collectivism) as one of the dimensions of national culture on the organization of the educational process in both universities. This index signifies to what extent individual characteristics and demands of people who want to get education are met by the universities, which is reflected in the number of educational programs available and the possibility to choose academic courses tailored to the students' needs.

According to the "Mission of the National Research Tomsk Polytechnic University" the goal of TPU is to enhance the competitiveness of the country, to improve the training of the engineering elite, to boost the generation of new knowledge, innovative ideas and resource- efficient technologies by integrating and internationalizing research, education, and practice. Apparently the Russian university views the process of training the engineering elite just as the process of reducing the number of undergraduate and graduate programs.
Table 2. The number of degree programs at TPU (2009 2015).

\begin{tabular}{|l|c|c|c|c|c|c|c|}
\hline & 2009 & 2010 & 2011 & 2012 & 2013 & 2014 & 2015 \\
\hline $\begin{array}{l}\text { Bachelor } \\
\text { degree }\end{array}$ & 41 & 55 & 51 & 45 & 47 & 39 & 31 \\
\hline $\begin{array}{l}\text { Diploma } \\
\text { Specialist }\end{array}$ & 92 & 10 & 10 & 7 & 7 & 5 & 5 \\
\hline Master & 39 & 50 & 45 & $\begin{array}{c}\text { no } \\
\text { data }\end{array}$ & 31 & 34 & 36 \\
\hline $\begin{array}{l}\text { Postgraduat } \\
\text { e }\end{array}$ & $\begin{array}{c}\text { no } \\
\text { data }\end{array}$ & $\begin{array}{c}\text { no } \\
\text { data }\end{array}$ & $\begin{array}{c}\text { no } \\
\text { data }\end{array}$ & $\begin{array}{c}\text { no } \\
\text { data }\end{array}$ & $\begin{array}{c}\text { no } \\
\text { data }\end{array}$ & $\begin{array}{c}\text { no } \\
\text { data }\end{array}$ & 21 \\
\hline Total & 172 & 115 & 106 & $\begin{array}{c}\text { no } \\
\text { data }\end{array}$ & 85 & 78 & 72 \\
\hline
\end{tabular}

Over the period from 2009 to 2015 TPU has been consistently reducing the number of educational programs, which, we believe, can neither accommodate the demands and aspirations of people seeking to get higher education and to pursue personal cognitive and professional interests, nor meet the challenges of the innovation-oriented country and the society. In contrast, AZU students are offered more than 250 undergraduate programs and more than 100 post-graduate programs in the liberal arts and sciences, design and arts, engineering, business, journalism, education, law, nursing, public policy, technology, and sustainability. These programs are distributed between 16 colleges and schools. As for the field of engineering \& technology, where the activities of TPU and ASU overlap, the latter offers its students 57 undergraduate and 84 graduate programs. Making the range of academic programs wider and increasing the enrollment numbers are essential for the AZU administration to achieve the aim of engaging students into the university community and encouraging them to succeed.

Another aspect to be compared here is the subject content of educational programs. We believe that the availability of a wide range of possible academic courses within the framework of an educational program testifies that the program of studies can be tailored to the demands of each student, thus encouraging their creativity, and, as a consequence, contributing to the implementation of the main goal of engineering education, prescribed by the CDIO Initiative, that is to educate engineers capable of conceiving new technical ideas and designing new products. The results of the comparison of the course content of the two undergraduate programs in Software Engineering in both universities are as follows:

- the Software Engineering program at TPU includes an interdisciplinary training module enabling to choose from seven elective courses covering mainly social and humane studies, for example engineering entrepreneurship, business communication, career technology;

- the Software Engineering program implemented at AZU comprises several modules of electives: 1) the module of «Humanities, Arts and Design (HU) And Cultural Diversity in the U.S. » embracing 94 courses including American Ethnic Literature, Jazz in America etc.; 2) the module of «Social-Behavioral Sciences», with 624 courses such as The Soviet Experiment, The 
Russian Empire etc.; 3) «Natural Science» divided into two parts: Natural Science - Quantitative (SQ) (57 courses, for example, Physical Sciences in Technology, Chemistry and Society etc.) and Natural Science General (SG) (23 courses, such as, Natural History of Arizona, Dangerous World etc.).

Thus, unlike the Russian counterpart, the American university offers a much bigger number of opportunities to design a learning strategy tailored to the needs and interests of a student. As a result, Russian universities produce a lot of specialists without noticeable difference in the range of knowledge, professional skills, abilities, experience. It is obvious that these graduates will be welcomed only at large companies with the demand for specialists possessing a standard set of characteristics. On the other hand, these graduates lacking some specific professional skills are not prepared for the careers in an innovation-driven economy or for the development of new spheres of scientific and technological activity.

\section{Conclusions and policy implications}

The results of the above-mentioned comparative analysis of the issues under discussion allow us to draw some conclusions.

The cultural background of the Russian and American societies makes their systems of engineering education inimitably special and unique, affecting the nature, content and the level of activity of the universities' and students' involvement in education and innovation processes.

Low involvement activity into and low outcomes of innovation processes of Russian universities result from many factors, including high Power Distance, low degree of catering for individual demands of students for education, lack of interaction between universities' administration and civil society institutions. As a consequence, although a number of Russian universities have joined the «5-100» national project, neither the state nor the universities can identify the specific benefits that the implementation of this program entails for the Russian society.

Research, education and innovation activities of Russian universities are not geared to the needs of the society and its individuals. It is the government represented by state-owned corporations and MIC enterprises that establishes the market for engineers and innovative products [23]. Therefore, the Russian economy fails to provide demand for specialists with unique competencies, and training those professionals according to specially tailored academic programs is an exceptional rather than common practice.

It is obvious that Russian universities in the present conditions cannot act as a flagship model for the development of an innovation economy. This conclusion can be confirmed by the fact that although the city of Tomsk ranks first in Russia for the ratio of the number of people with scientific degrees to the total population, and has two leading research universities and the innovative technology development special economic zone, it fails to attain the leading positions in the field of innovation development even among the regions of Siberia).

We cannot assess as positive those approaches to further development of Russian engineering education that conceptualize either the necessity of maintaining the continuity of the national system of engineering training or the urgency of transferring the world's best practices of engineering training. Both of the approaches, as the results of our study demonstrate, are in conflict with the cultural value imperatives of the innovation-oriented society.

Consequently, the only possible way for the development of the Russian system of engineering education is to integrate with the western systems on the condition that the value system of the Russian state and society is revised. In particular, there is urgency to establish and forge connections between universities and the civil society, which, due to the embryonic state of the latter in modern Russia, seems to be next to impossible to implement.

\section{Acknowledgements}

The article is supported by the Russian Humanitarian Science Foundation grant № 16-16-70006.

The authors are grateful to the Chmykhalo family (Diana, Dmitri and Michael) for their support and good advice.

\section{References}

1. M. Edwards-Schachter, A. García-Granero, M. Sánchez-Barrioluengo, H. Quesada-Pinedab, N. Amara, Thinking Sk. and Creat, 16, (2015)

2. D.T. Rover, Journ. of Eng. Edu., 94, (2005)

3. D.K. Gattie, N. K. Kellam, J. R. Schramski, J. Walther, Europ. Journ. of Eng. Edu., 36(6), (2011)

4. J. Vanevenhoven, Jour. of Small Bus. Man., 51(3), (2013)

5. G. Fastré, A. Van Gils, Competence development in entrepreneurship. The role of university education (2007)

6. M.H. Morris, J.W. Webb, J. Fu, S. Singhal, Journ. of Small Bus. Man., 51(3), (2013)

7. A. Fayolle, H. Klandt, International entrepreneurship education: Issues and newness (2006)

8. J. A. Katz, Journ. of Bus. Vent., 18(2), (2003)

9. H. Oosterbeek, M. Praag, A. Ijsselstein, Europ. Econ. Rev., 54, (2010)

10. L. Clarke, C. Winch, Journ. of Edu. and Work, 19(3), (2006)

11. A. L. Frank, Plan. Pract. and Res., 22(4), (2007)

12. T. Lans, H. Biemans, M. Mulder, J. Verstegen, Human Res. Dev. Quarterly, 21(2), (2010)

13. R. B. Brown, Manag. Learn., 25(2), (1994)

14. G. Cheetham, G. Chivers, Journ. of Eu. Ind. Train., 20(5), (1996)

15. A. Stoof, R. L. Martens, J. J. G. Van Merriënboer, T. J. Bastiaens, Human Res. Devel. Rev., 1, (2002) 
16. H. Etzkowitz, L. Leydesdorff, Res. Policy, 29, 2 (2000).

17. P. E. Petrakis, C. K. Pantelis, D. G. Valsamis, Journ. of Bus. Res., 68, (2015)

18. A. A. Aleksandrov, I.B. Fedorov, V.E. Medvedev, Vysshee obrazovanie v Rossii, 12, (2013)

19. I. B. Ardashkin, Procedia - Soc. and Behav. Sc., 166, (2015)

20. B. L. Agranovich, Y.P. Poholkov, P.S. Chubik, A.I. Chuchalin, Universitetskoe upravlenie, 1, (2009)

21. S. A. Podlesnyj, Vestnik Kazanskogo tekhnologicheskogo universiteta, 16, (2013)

22. M. A. Makienko, A. N. Panamareva, Procedia Soc. and Behav, 166, (2015)

23. A. Y. Chmykhalo, M. E. Abushaeva, Procedia Soc. and Behav., 166, (2015) 